\title{
K rozpadu Cyperskej republiky v 60. rokoch 20. storočia
}

\section{To the breakdown of the Republic of Cyprus in 60 years of $20^{\text {th }}$ century}

\author{
Erik Ondria / e.ondria@gmail.com \\ Inštitút histórie, Filozofická fakulta, Prešovská univerzita, Prešov, SK
}

\begin{abstract}
The birth of Cyprus republic in 1960 was significant milestone in Cyprus history. In august 1960 independent republic of Cyprus was established and it was also the end of long-running struggle of Cyprus's inhabitants (especially Greek Cypriots) for freedom. The creation of new state accepted and supported by the UN and a lot of world states. As time goes by, the new Republic established serious diplomatic contacts with many countries in the world. The contribution will be dedicated to the breakdown of the Republic of Cyprus in 60 years of $20^{\text {th }}$ century, with accent on 1963-1964 years, together with a point of view from domestic and foreign politics.
\end{abstract}

\section{Keywords}

The Republic of Cyprus -The years 1963 -1964 - Breakdown of Cyprus republic 
Hlavným zámerom tohto príspevku je priblí̌zit čitatelovi prehladovým spôsobom postupný „rozpad“ Cyperskej republiky prostredníctvom najpodstatnejších dejinných súvislostí cyperskej problematiky zo začiatku 60. rokov 20. storočia. V našom príspevku sa budeme zaoberat otázkami akým spôsobom bola kreovaná nezávislá Cyperská republika, kto stál pri jej zrode a aké boli najdôležitejšie faktory ovplyvňujúce postupný rozklad politických štruktúr republiky.

Pri spracovaní tejto témy sme vychádzali z archívnych materiálov Organizácie spojených národov. Z nich sme parciálne zužitkovali rezolúcie Rady Bezpečnosti OSN a rezolúcie Valného Zhromaždenia OSN. Použili sme tiež ústavu Cyperskej republiky, dostupnú v archíve Úradu prezidenta Cyperskej republiky.

Z literatúry ${ }^{1}$ sme využili niektoré vybrané práce britských, amerických, gréckych, tureckých, českých a slovenských autorov. Z monografických prác boli najprínosnejšie: Williama Mallinsona (Cyprus a historical overview, 2011), Pavla Hradečného (Řekové a Turci. Nepřátelé nebo spojenci, 2000), či napr. Roberta Stephensa (Cyprus a Place of Arms, 1966) Prínosná bola tiež práca autorského kolektívu Ivana Majchúta a Michala Hrnčiara z Akadémie ozbrojených síl M. R. Štefánika (Cyprus - dimenzie konfliktu, 2014).

Vedecké štúdie sú zastúpené najmä v periodikách gréckej (The Cyprus Review), grécko-americkej (The Journal of Modern Hellenism), tureckej (Ankara Bar Review) či zahraničnej proveniencie (International Journal of Middle East Studies).

\section{Cesta k vzniku Cyperskej republiky}

Na začiatku 20. storočia patrilo územie Cypru stále pod správu Velkej Británie. Tá Cyprus získala do prenájmu od Osmanskej ríše po Berlínskom kongrese v roku 1878. Po vypuknutí prvej svetovej vojny Vel'ká Británia ostrov anektovala. Po skončení prvej svetovej vojny sa Turecko podpisom Lausannskej zmluvy v roku 1923 vzdalo svojich nárokov na územie Cypru. Vel'ká Británia tak v roku 1925 vyhlásila Cyprus za svoju korunnú kolóniu a pomerne pokojne spravovala tento ostrov až do polovice 20. storočia.

Obdobie druhej polovice 50. rokov 20. storočia predstavuje v moderných cyperských dejinách etapu boja grécko-cyperského obyvatel'stva za samourčenie ostrova. Cyperskí Gréci si však samourčenie, v ich ponímaní enosis², vykladali ako spojenie Cypru s materskou krajinou Gréckom, v jednom štátnom celku. Tento boj bol v 50. rokoch 20. storočia zosobnený plukovníkom Georgiom Grivasom³ ${ }^{3}$ organizáciou EOKA ${ }^{4}$ a arcibiskupom

1 Okrem prác použitých v tejto štúdii sa v československej literatúre zaoberali skúmanou problematikou tiež: Pupti, Eleni: Některé úvahy o státním zř́zeni Kyperské republiky. Právník 100, 1961, s. 654-664; John, Jaroslav: Kypr. Praha 1964; Pupti, Eleni: Ústavni a politický systém Kyperské republiky. Praha 1973; okrajovo tiež Hradečný, Pavel: Řecká republika. Praha 1989; Hradečný, Pavel a kol.: Dějiny Řecka. Praha 1998; Z historiografie po roku 2000 napr.: Cabada, Ladislav: Politické systémy Kypru. In: Commonwealth Politické systémy. Praha 2007, s. 199-215.

2 Enosis - grécke slovo enosis znamená únia, spojenie. V prípade cyperských dejín 20. storočia je týmto slovom označovaná dlhotrvajúca snaha grécko-cyperského obyvatelstva o spojenie ostrova s Gréckom.

3 Georgios Grivas sa narodil 29. mája 1898 v dedine Trikomo, vo famagustskej oblasti (niektoré zdroje uvádzajú 5. či 6. jún 1897 a miesto narodenia Nikóziu). Študoval na Pancyperskom gymnáziu v Nikózii 
Makariom III. ${ }^{5}$ na strane jednej a vládou Vel'kej Británie a cyperskými Turkami, presadzujúcimi taksim ${ }^{6}$, na strane druhej. Krvavé boje na Cypre a diplomatická aktivita zúčastnených strán vyústili 16. augusta 1960 do vzniku Cyperskej republiky.

Cyperská republika existuje de iure ako štátny útvar prakticky dodnes, avšak v porovnaní s rokom 1960 v menšej rozlohe a zmenených hraniciach. Vývoj Cyperskej republiky v 60. rokoch 20. storočia de facto priniesol rozpad pôvodných štruktúr tohto štátu a rozdelenie oboch cyperských národností. Tie boli právne zakotvené v ústave republiky pri vzniku tohto štátu. Rozpad Cyperskej republiky je preto v tejto štúdii považovaný za rozpad štátu de facto.

Novovzniknutá Cyperská republika sa svojím vznikom prihlásila do medzinárodného spoločenstva ako suverénny a rovnocenný partner. Valné zhromaždenie Organizácie spojených národov dostalo 24. augusta 1960 odporúčanie Rady Bezpečnosti OSN pre prijatie

a na vojenských akadémiách v Aténach a vo Francúzsku. Napriek tomu, že bol pôvodom z Cypru, vstúpil do gréckej armády a zúčastnil sa grécko-tureckej vojny (1919-1923). Počas medzivojnového obdobia zastával viacero funkcií v gréckej armáde a neskôr povýšený na majora. Počas druhej svetovej vojny bojoval na fronte v Epire proti Talianom. Po okupácii Grécka nacistickými silami založil tajnú, krajne pravicovú organizáciu „X“ namierenú proti okupantom a komunistom v Grécku. Po skončení druhej svetovej vojny odišiel z gréckej armády a zameral sa na osamostatnenie Cypru, dosiahnutie enosis. Založil teroristickú organizáciu EOKA a v druhej polovici 50. rokov 20. storočia bojoval proti britským silám na Cypre. Po zisku Cyperskej nezávislosti bol gréckou vládou povýšený na generála. Zapojil sa do etnických konfliktov na Cypre v 60.. rokoch 20. storočia ako velitel' grécko-cyperskej Národnej gardy, no v druhej polovici tejto dekády musel z Cypru odíst́. Na ostrov sa vrátil v roku 1971 a obnovil organizáciu EOKA (už EOKA B). V tomto období už bol v opozícii proti prezidentovi Makariovi a bol tiež zapletený do atentátu na jeho osobu. Nedožil sa naplnenia snahy o spojenie Cypru s Gréckom. Zomrel 27. januára 1974.

4 EOKA - Národná organizácia cyperských bojovníkov (Ethniki organosi kyprion agoniston) založená v 50. rokoch 20. storočia. Bola riadená pravicovo extrémistickým plukovníkom Georgiom Grivasom. Cyperčanom, niekdajším vodcom antikomunisticky orientovanej tajnej organizácie „X“ (Chi), ktorá pôsobila v pevninskom Grécku v záverečnom období 2. svetovej vojny. Organizácia EOKA svoje útoky zo začiatku zameriavala proti „nevlasteneckým“ cyperským Grékom, neskôr sa však začala sústred’ovaṫ tiež na boj proti britskej koloniálnej správe a proti príslušníkom tureckej komunity na ostrove. Cielom tejto organizácie bolo radikálnymi teroristickými krokmi upozornit svetovú verejnost̉ na cyperskú otázku, vytlačit Britov z ich pozícií na ostrove a dosiahnut enosis. Arcibiskup Makarios III. nebol zo začiatku ochotný povolit násilný spôsob boja za nezávislost’ Cypru, nakoniec však po neúspešných rokovaniach na medzinárodnom fóre zmenil názor. Niekedy je EOKA v literatúre mylne spájaná so stranou AKEL ako jej ultrapravicové krídlo. Hradečný, Pavel a kol.: Dějiny Řecka. Praha 1998, s. 489-490.

5 Arcibiskup Makarios III. - vlastným menom Michail Christodoulou Muskos sa narodil 13. augusta 1913 v obci Pano Panayia na Cypre. Zomrel 3. augusta 1977 v Nikózii. Bol arcibiskupom a hlavou Pravoslávnej Cirkvi na Cypre a prezidentom Cypru v rokoch 1959-1977. Syn chudobného pastiera, vysvätený za kňaza v roku 1946, sa stal biskupom v roku 1948 a arcibiskupom v roku 1950. Podporovatel myšlienky zjednotenia Cypru s Gréckom. V rokoch 1955-1956 vyjednával s Britským guvernérom na Cypre o budúcnosti ostrova a jeho možného zlúčenia s Gréckom. Neskôr bol zatknutý za poburovanie a následne vyhostený. V roku 1959 akceptoval myšlienku nezávislosti pre Cyprus. V tom istom roku bol zvolený za prezidenta spolu s tureckým viceprezidentom. Dvakrát bol znovuzvolený a v roku 1974 utiekol z Cypru pri pokuse o palácový prevrat spáchaný gréckymi Cyperčanmi a Národnou gardou. Po Tureckej invázii na Cyprus v roku 1974 a zriadení oddeleného tureckého územia odmietol myšlienku rozdelenia ostrova.

6 Taksim - slovo z turečtiny, v preklade znamená rozdelenie,. V turecko-cyperskom ponímaní dejín 50. rokov 20. storočia symbolizovalo protiváhu grécko-cyperskej enosis. Cyperskí Turci predpokladali, že ak by enosis bola úspešná, boli by na Cypre perzekvovanou menšinou. Rozhodli sa preto presadzovat rozdelenie ostrova na Grécku a tureckú čast'. Mirbagheri, Farid: Historical Dictionary of Cyprus. Lanham-Toronto-Plymouth 2010, s. 158. 
Cyperskej republiky do členstva Organizácie spojených národov. ${ }^{7}$ Po zvážení cyperskej žiadosti prijalo Valné zhromaždenie OSN Cyperskú republiku za člena OSN 20. septembra $1960{ }^{8}$

Cyperskú republiku a obe jej značne diferencované národnosti čakala od začiatku zložitá skúška symbiózy. Ako sa však ukázalo, rozdiely a neústupnosṫ oboch cyperských komunít sa nepodarilo preklenút. Praktické príčiny postupného rozkladu zriadenia Cyperskej republiky bolo možno badat už pri kreovaní cyperskej ústavy a „garančných “ zmlúv ${ }^{9}$ z konca 50. a v menšej miere na začiatku 60. rokov 20. storočia. Tzv. zürišsko-londýnske dohody z februára 1959 vytvorili právnu základňu pre vyhlásenie nového štátu - Cyperskej republiky. Dohody boli výsledkom viacerých rokovaní a predstavovali súbor väčšieho počtu dokumentov (memoranda a deviatich pripojených rozhodnutí). Ich podpisom Grécko a cyperskí Gréci upustili od svojich snáh o enosis, Turecko a cyperskí Turci sa zaviazali nepresadzovat taksim, a Vel'ká Británia sa oficiálne zriekla svojej dovtedajšej vlády nad Cyprom. ${ }^{10}$

Hlavné zmluvy z februára 1959, o ktoré sa opierala cyperská nezávislost', boli Zmluva o garanciách, Zmluva o zriadení a Zmluva o spojenectve. ${ }^{11} \mathrm{~V}$ Zmluve o garanciách Grécko, Turecko a Vel'ká Británia zaručovali nezávislost', územnú integritu a bezpečnost’ Cyperskej republiky. V prípade narušenia niektorého zo zmienených základných atribútov mali garančné štáty spoločne posúdit možnosti d’alšieho postupu. Pre prípad, ak by sa ich koordinovaná akcia ukázala ako neuskutočnitel'ná, si každá z troch ručitel'ských krajín vyhradila právo podniknút individuálny zákrok na ostrove, ktorej jediným ciel’om mala byt reštaurácia stavu vecí, vytvorených touto zmluvou. Cyperská republika sa podl’a tejto dohody nesmela podielat’ ani úplne ani čiastočne na žiadnom politickom, či ekonomickom zväzku, ktorého členom by neboli všetci signatári zürišsko-londýnskych dohôd. ${ }^{12}$

Zmluva o spojenectve Cyperskej republiky s Gréckom a Tureckom umožňovala obom materským krajinám udržiavat na Cypre svoje vojenské kontingenty vo vopred určenom vzájomnom pomere 60 : 40 (950 Grékov k 650 Turkom). Tento číselný vztah bol určený bez ohladu na etnický pomer ${ }^{13}$ oboch komunít na ostrove a rovnaký kl’úč platil i pre dvojtisícovú cyperskú armádu. ${ }^{14}$ Oba zmienené vojenské kontingenty mali na ostrove spojené armádne velitel'stvo pre lepšiu koordináciu v prípade výskytu možných nezhôd.

7 Rozhodnutie Valného Zhromaždenia OSN o prijati Cyperskej republiky do členstva Organizácie spojených národov zo dňa 20.9.1960. Internetový archív OSN, http://www.securitycouncilreport.org/atf/cf/\%7B65BFCF9B6D27-4E9C-8CD3-CF6E4FF96FF9\%7D/UNMembers\%20ARES1489\%20XV.pdf,_citováno 12. 3. 2018.

8 Rozhodnutie Valného Zhromaždenia OSN o prijati Cyperskej republiky do členstva Organizácie spojených národov zo dňa 20.9.1960. Internetový archív OSN, http://www.securitycouncilreport.org/atf/cf/\%7B65BFCF9B6D27-4E9C-8CD3-CF6E4FF96FF9\%7D/UNMembers\%20ARES1489\%20XV.pdf, citováno 12. 3. 2018.

9 Zürišsko-londýnske dohody z februára 1959 sa častokrát v literatúre označujú ako garančné, ked’že svojim spôsobom garantovali vznik a fungovanie Cyperskej republiky.

10 Hradečný, Pavel.: Řekové a Turci. Nepřátelé nebo spojenci? Praha 2000, s. 80.

11 Mallinson, William: Cyprus a historical overview. Nicosia 2011, s. 24.

12 Hradečný, P.: Řekové a Turci, s. 82.

13 Etnický pomer na Cypre predstavoval približne 80\% cyperských Grékov voči 18\% cyperských Turkov. Zvyšné dve percentá tvorili Arméni, Maroniti, Židia a iné menšiny.

14 Mallinson, W.: Cyprus a historical overview, s. 24. 
V Zmluve o zriadení bolo popísané právne zloženie Cyperskej republiky. Podla tejto zmluvy mala Vel'ká Británia právo na používanie dvoch oblastí, vojenských základní Dekelia a Akrotiri, ktoré zostali pod jej suverenitou. Presné vymedzenie územia oboch základní musela vláda Vel'kej Británie prerokovat so zástupcami oboch cyperských komunít, arcibiskupom Makariom III. z grécko-cyperskej strany a Fazılom Küçükom ${ }^{15}$ zo strany turecko-cyperskej. Z pôvodnej požiadavky 170 štvorcových míl' sa nakoniec podarilo zástupcom Vel'kej Británie vyrokovat 99 štvorcových míl' (približne 256 kilometrov štvorcových). ${ }^{16}$

V konečnom dôsledku vyšli z zürišsko-londýnskych dohôd vo väčšej miere posilnení tureckí obyvatelia Cypru, kedže aj napriek ich menšej početnosti (18\% z populácie ostrova) získali v úradoch republiky až $30 \%$ miest. Navyše, cypersko-tureckí predstavitelia dostali právo veta v oblasti zahraničných rozhodnutí, obrany, bezpečnosti a daňového zataženia. ${ }^{17}$ Zvýhodnenie cyperských Turkov v novom štáte malo pôvod už pri rokovaniach o vzniku Cyperskej republiky. Za posilnenými cypersko-tureckými právami stálo predovšetkým pevninské Turecko. Z najvýznamnejších faktorov ovplyvňujúcich rozhodnutie v posilnení tureckých práv na ostrove možno uviesṫ spoluprácu cyperských Turkov s britskými úradmi v druhej polovici 50. rokov 20. storočia, potlačenie prípadných grécko-cyperských snáh o enosis v novom štáte, výraznú tureckú diplomatickú aktivitu a postavenie Turecka pri týchto rokovaniach a jeho pozície vrámci širších intenciách studenej vojny a geopolitickom priestore, v ktorom sa krajina nachádzala, či geografická blízkost’ pevninského Turecka k Cypru.

Ústava Cyperskej republiky rozdel'ovala občanov ostrova na základe etnického pôvodu a náboženstva na dve komunity. Príslušníci iných národností sa museli zaradit medzi cyperských Grékov alebo cyperských Turkov. Za riadiace zložky oboch národných spoločenstiev boli ustanovené Komunálne komory, akési „malé parlamenty, “ zodpovedajúce za záležitosti vrámci vlastnej národnej obce, ako bolo napríklad náboženstvo a vzdelanie. Komunálne komory mali byt volené všetkými príslušníkmi danej národnosti. Najvyšším legislatívnym orgánom Cyperskej republiky sa stal 50-členný parlament, kde spoločne zasadali cyperskí Gréci i cyperskí Turci. Zastúpenie cyperských Grékov predstavovalo 35 kresiel (70\%), a 15 kresiel bolo stanovených pre (30\%) turecko-cyperských poslancov. Príslušníci oboch spoločenstiev volili poslancov svojich národných komunít oddelene. Pre prijatie akéhokolvek zákona bolo potrebné pri hlasovaniach dosiahnut dvojitú väčšinu, čiže absolútnu väčšinu hlasov ako gréckych, tak aj tureckých politikov. ${ }^{18}$

15 Fazıl Küçük sa narodil v Nikózii v roku 1906. Študoval v Istanbule, Francúzsku a Švajčiarsku. V máji 1937 sa vrátil na Cyprus ako kvalifikovaný všeobecný lekár. Küçük bol oponentom britskej vlády na ostrove a obhajoval turecko-cyperské práva. V priebehu 50. rokov 20. storočia založil svoju vlastnú politickú stranu. Založil tiež prvý turecký pracovný zväz na Cypre a noviny Halkin Sesi (Hlas ludu). Bol hlavným reprezentantom cyperských Turkov na rokovaniach v rokoch 1959 a podpísal zürišsko-londýnske dohody. Stal sa prvým viceprezidentom Cyperskej republiky. V roku 1973 ho na poste turecko-cyperských lídrov vystriedal Rauf Denktaş. Fazil Küçük zomrel v roku 1984. Mirbagheri, F.: Historical Dictionary of Cyprus 2010, s. 91-92.

16 Varnava, Andrekos: Reinterpreting Macmillan's Cyprus Policy, 1957-1960. The Cyprus Review 22, 2010, č. 1, s. 100 .

17 Mallinson, W.: Cyprus a historical overview, s. 25.

18 Hradečný, P.: Řekové a Turci, s. 81. 
Prezident krajiny mal byt priamo zvolený cyperský Grék pochádzajúci z gréckej komunity, viceprezident mal byt cyperský Turek zvolený z tureckej komunity. Viceprezident mal právo veta, ktoré mohol použit pri zákonoch, ktoré schválil parlament a pri rozhodnutiach Rady ministrov. ${ }^{19}$ Obaja najvyšší štátni funkcionári nedisponovali právom vzájomne sa zastupovat'. Podla svojej národnej príslušnosti však mohli odvolávat ministrov a navzájom vetovat svoje rozhodnutia, či uznesenia parlamentu v otázkach týkajúcich sa zahraničnej politiky, obrany a bezpečnosti. ${ }^{20}$ Rada ministrov mala byt zložená z 10 osôb, z ktorých traja mali byt tureckí Cyperčania nominovaní viceprezidentom. ${ }^{21}$

Signatári zürišsko-londýnskych dohôd síce deklarovali, že sa Cyprus stane nezávislou, zvrchovanou a jednotnou prezidentskou republikou, no akceptovali niekol'ko ustanovení, ktoré neboli v súlade so zásadami zvrchovanosti nového štátu ani s princípmi jeho unitárneho riadenia. Vyhlásenia zmluvných strán zürišsko-londýnskych dohôd v sebe tiež zahŕňali prvky svojrázneho federálneho usporiadania, ktoré poskytovalo menšinovým cyperským Turkom ochranu pred ich majorizáciou zo strany cyperských Grékov. $^{22}$

Významnú úlohu v štátnej sústave Cyperskej republiky zohrával trojčlenný Najvyšší ústavný súd, ktorý bol zložený z dvoch cyperských občanov (jedného Gréka a jedného Turka) a nezávislého predsedu z tretej krajiny. Predseda nemal byt občan Grécka či Turecka, ani príslušník jednej z krajín Britského Commonwealthu. K širokej palete kontrolných a arbitrážnych právomocí Najvyššieho trojčlenného súdu patrilo rozhodovanie o záväznom výklade ústavy, o ústavnosti zákonov, o sporoch medzi štátnymi orgánmi, o platnosti volieb a o obsadzovaní miest v štátnych inštitúciách v prípadoch, ktoré by nebol schopný rozhodnút tzv. Výbor verejných služieb. Tento výbor bol zvláštny výkonný orgán, zložený zo siedmych cyperských Grékov a troch cyperských Turkov. ${ }^{23}$ Pomer 70:30 v štátnej správe tak ostával zachovávaný.

\section{Cyperská republika v rokoch 1960-1963}

Ako sme už spomínali, Cyperskú republiku čakala od jej založenia zložitá skúška symbiózy. Ak mal nový štát fungovat, bolo potrebné prekonat priepastné rozkoly medzi mocenskými elitami oboch národných komunít a dosiahnut', aby cyperskí Gréci a cyperskí Turci spolupracovali pri napíňaní princípov stanovených v dohodách z Zürichu a Londýna zo záveru 50. rokov 20. storočia. Nemenej dôležitá bola praktická aplikácia ustanovení ústavy, ktorá z predmetných dohôd vychádzala. No k realizácii týchto základných predpokladov fungovania nového štátu nedošlo, rovnako ako nedošlo ani k vytvoreniu vzájomnej dôvery medzi oboma cyperskými národnostami. Cyperská republika bola od okamihu

19 Bora, Erhan: Cyprus in International Law. Ankara Bar Review 6, 2013, č. 1, s. 34.

20 Hradečný, P.: Řekové a Turci, s. 82.

21 Bora, Erhan: Cyprus in International Law, s. 34.

22 Hradečný, P.: Řekové a Turci, s. 81.

23 Tamtéž, s. 82. 
svojho vzniku zmietaná vzrastajúcimi rozpormi. Istá časṫ cyperských Grékova sa nevzdala myšlienky na enosis. Cítili sa poškodení a ponížení právomocami, ktoré ústava garantovala cyperským Turkom. Tých navyše podozrievali zo snáh o pretvorenie jednotného cyperského štátu na federáciu a na základe týchto úvah obchádzali ustanovenia ústavy. Svoj postup zdôvodňovali nefunkčnostou zavedeného štátneho systému a jeho zablokovaním zo strany turecko-cyperskej komunity. Cyperskí Turci trvali na striktnom uplatnení všetkých článkov ústavy, pretože sa obávali, že sa cyperskí Gréci pokúsia odstránit ich rovnoprávne postavenie v systéme Cyperskej republiky. Podla cyperských Turkov si cyperskí Gréci pripravovali pôdu pre ich enosis „krétskou cestou“, t.j. odstránením Turkov zo štruktúr Cyperskej republiky a spojením ostrova s Gréckom po krátkom období existencie formálne nezávislého štátu. ${ }^{24}$

Zriadenie Cyperskej republiky tak vnímali odlišne obe jej národnosti. Tureckí predstavitelia cyperského obyvatel'stva zastávali každý článok ústavy, zatial čo cyperskí Gréci žiadali zásadné zmeny „vnútenej ústavy“. Prvé nezhody tak na seba nenechali dlho čakat a objavili sa v podobe problematickej implementácie pomeru 70:30 v prospech miest v štátnej správe pre cyperských Grékov. Gréci na Cypre nazerali na toto nariadenie ako na diskriminačné, spôsobujúce stratu pracovných pozícií pre svoju komunitu. Podla cyperských Grékov spôsobovalo priradenie $30 \%$ miest v správe cyperským Turkom štátu značné tažkosti. Pri vymenovávaní do funkcií a pri povýšeniach bolo potrebné použit kritériá, ktoré neboli všeobecne využívané. Išlo o schopnosti uchádzača, kvalifikáciu, výkonnost', vhodnosṫ jednotlivých kandidátov na miesta v správe, ked’̌̌e bolo prirodzené, že zvolená osoba na vy̌šom poste v štátnej správe bude musiet vydávat rozhodnutia, v ktorých bude musiet vziat do úvahy aj etnické a komunitné faktory. Predpísaný systém neodvratne smeroval $\mathrm{k}$ výsledku, v ktorom jednoducho nemohli byt vždy zvolení najvhodnejší kandidáti. Značné komplikácie priniesol zložitý systém povýšení v štátnej správe. Štátni úradníci, ktorí mali všetky potrebné kvalifikácie a skúsenosti pre povýšenie, boli často prehliadaní $\mathrm{v}$ prospech menej kvalifikovaných úradníkov, ktorí boli pri povýšeniach uprednostňovaní kvôli zachovaniu umelého národnostného pomeru v štátnej správe. Cyperskí Turci vnímali pomer miest $70: 30$ ako základ pre zastúpenie tureckej komunity vo všetkých sférach vládnych aktivít. Bez tohto pomeru by podla nich boli cyperskí Gréci schopní získat kontrolu nad vládou na ostrove, a to nebolo prístupné vzhladom na nedávne udalosti z 50. rokov 20. storočia. ${ }^{25} \mathrm{~V}$ Cyperskej republike navyše panoval nedostatok vzdelaných cyperských Turkov vhodných na vykonávanie úradníckych funkcií.

Jeden z d’alších výrazných problémov Cyperskej republiky v rokoch 1960-1963 spočíval v právach na odvody daní v komunálnych komorách. Tieto inštitúcie zaviedli dane na dosiahnutie cielov tej ktorej komunity, avšak najmä v otázke vzdelávania boli tieto ustanovizne podporované grantmi centrálnej vlády. Keď̌e obe komunity zaviedli dane prostredníctvom svojich komôr, vedúci predstavitelia týchto komunít neboli ochotní prijímat dalšie zdanenie centrálnej vlády potrebné tiež na podporu spomínaných

24 Hradečný, P.: Řekové a Turci, s. 87-88.

25 Polyviou, Polyvios G.: Cyprus Conflict and Negotiation 1960-1980. New York 1980, s. 25-26. 
dodatočných grantov. ${ }^{26}$ Už v roku 1961 cyperskí Turci tvrdili, že predstavitelia ich spoločenstva nedostali ústavou zaručených $30 \%$ miest v štátnom a verejnom sektore, a tak znemožnili prijatie dvoch nových daňových zákonov. ${ }^{27}$ Výsledkom nezhôd v prijímaní prvotných daňových zákonov bola skutočnost', že Cyperská republika v konečnom dôsledku nemala prijaté riadne daňové zákony. Nebola zriadená žiadna inštitúcia na výmer a vyberanie daní. Obe spoločenstvá tak boli nakoniec financované z daní, ktoré vybrali od svojich vlastných príslušníkov komunít. ${ }^{28}$

Formovanie a vývoj cyperskej armády sa čoskoro stali d’alším rozdelujúcim prvkom Cyperskej republiky. Plánovanie kádrov cyperskej armády nikdy neprekročilo jadro dôstojníkov-kadetov. Namiesto toho si obe cyperské komunity začali tajne trénovat a vyzbrojovat vlastné armády. Dohody podpísané pred vznikom Cyperskej republiky umožňovali novému štátu vytvorit armádu o sile 2000 mužov, pozostávajúcich z cyperských Grékov a cyperských Turkov vo vzájomnom pomere 60:40. Tureckí lídri požadovali, aby boli grécke a turecké jednotky oddelené. Turecko-cyperský minister obrany Osman Örek ${ }^{29}$ tvrdil, že ho grécko-cyperský velitel' armády ubezpečoval, že z praktických dôvodov v jazykových a náboženských zvyklostiach by mali byt vytvorené oddelené jednotky na úrovni čaty a družstva. Prezident Makarios však rozhodol, že armáda sa nebude štiepit na žiadnej úrovni. Toto rozhodnutie bolo vetované viceprezidentom F. Küçükom. Prezident Makarios preto vyhlásil, že bude lepšie, ak Cyperská republika nebude mať žiadnu armádu, ked’že Cyprus je členom Hnutia nezúčastnených krajín a navyše má limitované zdroje. Grécko-cyperskí kadeti plánovanej cyperskej armády, bývalí príslušníci organizácie EOKA, tak boli nakoniec využití pri cvičení tajnej grécko-cyperskej „armády“. ${ }^{30}$ Ozbrojené sily Cyperskej republiky nakoniec vytvorené neboli.

Zdanlivo najpálčivejším problémom bola otázka municipalít - mestských samospráv, či už oddelených alebo spojených. Problematika municipalít bola na Cypre definovaná v Cyperskej ústave z roku 1960, v článku 173, odseku 1. ${ }^{31}$ Cyperský prezident a viceprezident sa mali v období štyroch rokov od vstúpenia ústavy do platnosti dohodnút na ponechaní či zrušení oddelených národných municipalít. Oddelené grécke a turecké

26 Stephens, Robert: Cyprus a Place of Arms. London 1966, s. 175.

27 Hradečný, P.: Řekové a Turci, s. 88.

28 Khashman, Zeliha: Cyprus: The Challenge of Nationalism and the Question of a Federal Solution. Dissertation. Leicester 1997, s. 203.

29 Osman Örek - prvý minister obrany nezávislej Cyperskej republiky. Narodil sa v Nikózii v roku 1925. Vyštudoval právo na Istanbulskej a Londýnskej univerzite v roku 1952. V 50. rokoch 20. storočia pôsobil ako advokát na Cypre. Zapojil sa do rokovacieho procesu v súvislosti s dohodami ustanovujúcimi Cyperskú republiku. Po etnickom konflikte v rokoch 1963-1964 a prevzatí všetkých politických funkcií Cyperskej republiky Grékmi pôsobil pri OSN ako predstavitel' turecko-cyperskej autonómnej administratívy. Tento post zastával do roku 1976, kedy bol zvolený za člena parlamentu novoustanoveného Tureckého federatívneho štátu Cyprus, neskôr bol aj jeho premiérom. Podielal sa na príprave ústavy Tureckej republiky severného Cypru a neskôr pôsobil ako profesor medzinárodného práva na Univerzite východného Stredomoria. Zomrel v Londýne 24. marca 1999. People Ẽ life - Osman Örek First Minister of Defence of 1960 Republic of Cyprus, http://www.cypnet.co.uk/ncyprus/people/famous/ppl-osmanorek.htm, citováno 31. 5. 2018.

30 Stephens, R.: Cyprus a Place of Arms, s. 174-175.

31 Ústava Cyperskej republiky, http://www.presidency.gov.cy/presidency/presidency.nsf/all/1003AEDD83EED9C7C225756F0023C6AD/\$file/CY_Constitution.pdf, citováno 12. 3. 2018. 
municipality mali vzniknút v piatich najväčších Cyperských mestách - Nikózia, Larnaka, Limassol, Pafos a Famagusta (oblast Kyrenia bola vyňatá z dôvodu minimálneho zastúpenia občanov tureckého pôvodu). Prezident Makarios predložil návrh na spoločné obecné zastupitel'stvá, v ktorých by grécka čast’ spravovala výhradne grécke štvrte miest a turecká turecké. Zmiešané časti miest mali byt’ spravované spoločnými komisiami s pomerným zastúpením podla počtu obyvatelov. ${ }^{32}$ Grécko-cyperská väčšina videla v oddelených municipalitách separatistické snahy cyperských Turkov, a preto žiadala ich zjednotenie. Jednoduchou väčšinou v pomere obyvatel'stva by si tak zabezpečila rozhodujúcu silu v ich vedení. Začiatkom roka 1963 predniesli turecko-cyperskí poslanci návrh predíženia obdobia trvania oddelených municipalít, čím skončil celý problém pred Ústavným súdom, ktorému predsedal Dr. Ernst Forsthoff ${ }^{33}$. Výsledkom tohto sporu bolo prehĺbenie vládnej krízy. Cyperská republika nemala v konečnom dôsledku vyriešenú otázku municipalít. ${ }^{34}$

Závažnému problému cyperských municipalít navyše nepomáhali sporné vyjadrenia cyperského prezidenta Makaria. Ten veril, že nezhody medzi oboma cyperskými stranami budú považované za internú záležitost’ suverénneho štátu a v prípade komplikácií sa medzinárodné spoločenstvo postaví na stranu majoritných cyperských Grékov. ${ }^{35}$ Medzi rokmi 1960 a 1963 prezident Makarios verejne kritizoval dohody z Londýna a Zürichu. Riešenie, ktoré zakotvovali označoval za nestále a zároveň za pozostatok koloniálnej histórie ostrova. ${ }^{36}$

Po troch rokoch negatívnych skúseností s fungovaním Cyperskej republiky dospel prezident Makarios k názoru, že v jej zákonoch existujú určité ustanovenia, ktoré ohrozujú hladké fungovanie štátu. Tvrdil, že je potrebná revízia, ktorá zmaže niektoré prekážky brániace cyperským Grékom a cyperským Turkom v kooperácii v duchu porozumenia a priatel'stva. ${ }^{37}$ Grécko-cyperská snaha o revíziu ústavy začala narastat. Od leta 1963 kritizoval prezident Makarios vo svojich vyhláseniach intervenčné práva vlád Vel'kej Británie, Grécka a Turecka, implementované v dohodách podpísaných pred vznikom Cyperskej republiky. Intervenčným právom týchto mocností sa prakticky negovala nezávislost Cyperskej republiky. Túto problematiku chcel tiež uviest’ na konferencii premiérov Commonwealthu. Britská diplomacia poradila prezidentovi Cyperskej republiky, že tento krok by bol vel'mi nevhodný, nakol'ko medzi Gréckom a Tureckom pretrváva stále napätá situácia. Avšak pád Karamanlisovej vlády v Grécku a pokračujúca nestabilná politická situácia v Turecku začali komplikovat’ konštitucionálne problémy na Cypre. Ako prezident

32 John, Jaroslav: Kypr. Praha 1964, s. 57.

33 Ernst Forsthoff - profesor z Univerzity v Heidelbergu zo SRN. Medzinárodne uznávaný právnik a právny teoretik, predseda Cyperského Najvyššieho ústavného súdu. Neskôr kvôli nerešpektovaniu rozhodnutiam tohto súdu abdikoval na svoju funkciu.

34 Panteli, Stavros: The Making of Modern Cyprus. From Obscurity to Statehood. Nicosia 1990, s. 194.

35 Ako príklad možno uviest’ snahy inej minoritnej komunity. Išlo o prípad snáh o odtrhnutie provincie Katanga od Konga medzi rokmi 1960-1964, ktoré OSN odsúdila.

36 Bölükbaşi, Suha: The Cyprus Dispute and the United Nations: Peaceful Non-Settlement between 1954 and 1996. International Journal of Middle East Studies 3, 1998, s. 415.

37 Adams, Thomas W.: US army area handbook for Cyprus. Washington 1964, s. 249. 
Makarios, tak aj vodcovia cyperských Turkov boli pod stálym tlakom extrémistov požadujúcich enosis a taksim. ${ }^{38}$

Počas Makariovej prvej návštevy v Ankare v novembri 1962 turecká vláda výslovne varovala cyperského prezidenta, že akýkol’vek pokus o zmenu ústavného zriadenia bude v Turecku považovaný za najzávažnejší problém. Grécka vláda na druhej strane apelovala na prezidenta Makaria, aby v tejto otázke postupoval vel'mi obozretne. V tajnom liste pre prezidenta Makaria z apríla 1963 zdôraznil grécky minister zahraničných vecí Evangelos Averoff-Tositza ${ }^{39}$, že akýkol'vek pokus o zmenu dohôd z roku 1960 by viedol k rozloženiu vzţahov medzi cyperskými Grékmi a Turkami a súčasne by sa tým obnovila hrozba širšieho grécko-tureckého konfliktu. ${ }^{40}$

Vývoj udalostí na Cypre nehladiac na varovania Ankary a Atén smeroval nezadržatel'ne k novému ozbrojenému konfliktu. Prezident Makarios bol odhodlaný odstránit negatívne aspekty, ktoré podpísal pred vznikom republiky, s cielom ukončit koloniálnu nadvládu Vel'kej Británie. Priamym podnetom k novému konfliktu sa stalo memorandum, ktoré predložil prezident Makarios viceprezidentovi Cyperskej republiky Fazilovi Küçükovi 30. novembra $1963 .{ }^{41}$ Memorandum obsahovalo návrh na prijatie dodatočných 13 bodov $^{42} \mathrm{k}$ ústave. ${ }^{43}$

Prezident Makarios predložil svojich 13 dodatkov k cyperskej ústave bez konzultácie s gréckou vládou. Proti tomuto kroku boli tiež niektorí členovia jeho kabinetu. Zrejme neprekvapí, že spomínaných 13 bodov predstavovalo značnú unifikáciu cyperského života a eliminovalo vel'kú čast’ rozdel'ujúcich klauzúl z dohôd podpísaných pri vzniku Cyperskej republiky a cyperskej ústavy. Najdôležitejšie návrhy predstavovali zrušenie práva veta prezidenta a viceprezidenta republiky, zrušenie klauzúl týkajúcich sa oddelených väčšín v parlamente, unifikáciu administratívy spravodlivosti, municipalít a bezpečnostných zložiek. Kompozícia cyperských Grékov a cyperských Turkov v štátnej službe a armáde mala byṫ nahradená pomerom $80: 20$, namiesto $70: 30 \mathrm{v}$ štátnej službe, respektíve $60: 40 \mathrm{v}$ armáde. Prijatím týchto návrhov by cyperskí Turci stratili rovnocenné postavenie s cyperskými Grékmi a v štáte by sa z nich stala prakticky menšina. ${ }^{44}$

38 Stephens, R.: Cyprus a Place of Arms, s. 177-178.

39 Evangelos Averoff-Tositza - narodil sa v roku 1910 v Trikale v Grécku. Študoval právo na Univerzite v Lausanne vo Švajčiarsku. Počas druhej svetovej vojny bol aktívnym členom odbojového hnutia. Bol zajatý a väznený v Taliansku. V roku 1943 sa mu podarilo ujsţ a pokračoval v odboji do konca vojny. Medzi rokmi 1956-1963 pôsobil ako minister zásobovania, minister národnej ekonómie a obchodu a nakoniec ako minister zahraničných vecí. Dvakrát ho uväznili (v roku 1967 a 1974) ako oponenta diktátorov v Grécku. Bol jedným z najvplyvnejších osôb pri kreovaní zürišsko-londýnskych dohôd. Mirbagheri, F.: Historical Dictionary of Cyprus, s. 18-19.

40 Ker-Lindsay, James: Britain and the Cyprus Crisis, 1963-1964. Möhnesee 2004, s. 25.

41 Lindley, Dan - Wenzke, Caroline: Dismantling the Cyprus Conspiracy: The US role in the Cypriot Crises of 1963,

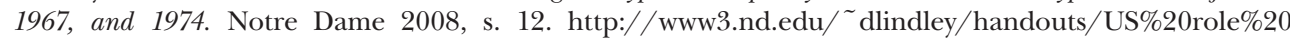
in\%20Cyprus\%20Crises.pdf, citováno 9. 3. 2008.

42 Oficiálny názov tohto memoranda bol: „Navrhované opatrenia na ulahčenie hladkého chodu štátu a odstránenie akýchkolvek sporov a medzikomunitných treníc.“

43 Nicolet, Claude: United States Policy Towards Cyprus, 1954-1974: Removing the Greek-Turkish Bone of Contention. Möhnesee 2001, s. 184.

44 Tamtéž, s. 185. 
Kópie dokumentu zaslal prezident Makarios všetkým trom signatárom zürišsko-londýnskych dohôd, tzv. garančným mocnostiam - Vel'kej Británii, Grécku a Turecku. Makariom navrhované doplnky ústavy Cyperskej republiky predstavovali zásadnú revíziu doterajších ústavných pomerov v krajine. V prípade uskutočnenia navrhovaných dodatkov by sa Cyperská republika zmenila v integrovaný unitárny štát, v ktorom by bolo zrušené právo veta tureckého spoločenstva. Podiel cyperských Turkov na obsadzovaní miest v štátnom a verejnom sektore by sa znížil z $30 \%$ na $20 \%$, podla zastúpenia približného počtu obyvatel'stva ostrova. Cyperskí Turci by prišli o svoje oddelené municipality, o vlastné súdy a o miesto doterajšieho rovnoprávneho postavenia v Cyperskej republike. Ako vláda v Ankare, tak aj turecko-cyperskí politici jednoznačne odmietli Makariov pokus o jednostrannú zmenu ústavy. ${ }^{45}$

Viceprezident F. Küçük obvinil, v oficiálnej turecko-cyperskej odpovedi na Makariovo memorandum, grécko-cyperskú stranu z vedomého neimplementovania tých častí ústavy, ktoré zvýhodňovali cyperských Turkov. Küçük tiež dodal, že ústava obsahovala mnoho jedinečných ustanovení, aké neobsahovala žiadna iná ústava sveta, no tie boli potrebné kvôli zvláštnej povahe cyperského problému. Išlo predovšetkým o existenciu dvoch komunít na ostrove, geografickú blízkosț Turecka a zámer pevninského Grécka anektovat Cyprus. ${ }^{46}$

Cyperská ústavná kríza niekol'ko dní po tureckom odmietnutí memoranda prezidenta Makaria prerástla 21. decembra 1963 v ozbrojený konflikt. V hlavnom meste Nikózii a v d’alších mestách na ostrove vypukli boje medzi policajnými jednotkami a organizáciami jednotlivých národných spoločenstiev. Tieto ozbrojené zrážky prerástli vzápätí do etnickej vojny charakterizovanej vzájomným zabíjaním, zajímaním rukojemníkov a útekom mnohých občanov Cypru zo svojich domovov. Obe národné komunity sa vzájomne obviňovali z vyvolania násilností. Najväčší počet obetí bol na strane cyperských Turkov, ktorí predstavovali v tomto konflikte slabšiu a ohrozenejšiu čast. Okolo 25000 Turkov zo 103 obcí utieklo, od decembra 1963 do marca 1964, zo svojich domovov do tureckých enkláv v severných častiach ostrova. Enklávy na severe ostrova boli uzavreté a strážené grécko-cyperskými a gréckymi silami ilegálne pôsobiacimi na ostrove. ${ }^{47}$

Etnické násilie na Cypre v 60. rokoch 20. storočia spôsobilo na ostrove masové populačné zmeny a presuny obyvatel'stva. Počas obdobia medzi decembrom 1963 a augustom 1964 bolo zabitých približne 350 tureckých Cyperčanov a 200 gréckych. ${ }^{48}$ Bolo vytvorených 39 turecko-cyperských enkláv, ktoré sa rozprestierali na $4 \%$ teritória Cypru. Najväčšia a najdôležitejšia enkláva sa rozprestierala medzi Nikóziou a Kyreniou. ${ }^{49}$

Začiatkom marca 1964 odsúhlasila OSN vytvorenie mierových síl, ktoré mali stabilizovat situáciu nad krízou zmietanom ostrove. Na základe rezolúcie č. 186 Rady Bezpečnosti OSN zo 4. marca 1964 boli vytvorené mierové sily Organizácie spojených národov

45 Hradečný, P.: Řekové a Turci, s. 89.

46 Polyviou, P. G.: Cyprus Conflict and Negotiation, s. 29.

47 Majchút, Ivan - Hrnčiar, Michal: Cyprus - dimenzie konfliktu. Liptovský Mikuláš 2014, s. 70.

48 Ioannides, Christos: Cyprus, British Colonialism and the Seeds of Partition: From Coexistence to Communal Strife. The Journal of Modern Hellenism 30, 2014, s. 66.

49 Tamtéž. 
na Cypre (UNFICYP). Skladba a vel'kost̉ kontingentu mierových síl mala byt určená, po konzultáciách s vládami Cypru, Grécka, Turecka a Spojeného Královstva Vel'kej Británie a Severného Írska, generálnym tajomníkom OSN, Velitel jednotiek mal byt určený a podriadený generálnemu tajomníkovi OSN. Generálny tajomník OSN mal povinnost’ pravidelne informovat Radu Bezpečnosti o priebehu a výsledkoch operácie. Rezolúcia č. 186 d’alej povolovala zriadit’ so súhlasom všetkých garančných mocností a cyperskej vlády sprostredkovatela s cielom podporovat' mierové riešenia. ${ }^{50}$

Na základe rezolúcie č. 187 Rady Bezpečnosti OSN z 13. marca 1964 zahájil mierový zbor jednotiek OSN UNFICYP svoju ochrannú a sprostredkovaciu činnosṫ v Cyperskej republike. ${ }^{51}$

\section{Záver}

Na konci 50. rokov 20. storočia zaznamenala cyperská otázka značnú medzinárodnú pozornost̉ v dôsledku medzikomunitného násilia, ktoré na ostrove vypuklo. Vznik Cyperskej republiky v roku 1960 bol podmienený medzinárodnými dohodami, ktoré v istej miere obmedzovali nezávislé fungovanie štátu. Najvyšší nárast internacionalizácie cyperskej problematiky môžeme badat práve kvôli občianskej vojne z rokov 1963-1964, v dôsledku ktorej bola tiež ustanovená mierová misia OSN UNFICYP, pôsobiaca na ostrove prakticky dodnes.

Nepokoje na Cypre zo začiatku 60. rokov 20. storočia patria k pomerne negatívnym medzníkom cyperských dejín. Dianie na Cypre sa opät stalo predmetom medzinárodnej politiky. Zánik dovtedajšieho ústavného zriadenia však znamenal pre obyvatel'stvo ostrova nový začiatok. Po uzavretí prímeria sa dostali cyperskí Turci do tažkej situácie, ktorá sa dá ohraničit rokmi 1963 až 1974. Vytvorili si vlastnú vládu známu ako Hlavný výbor, ktorý sa snažil vyriešit problém presídlenia viac ako 25000 obyvatelov. Pomoc Hlavnému výboru v jeho snahách prišla najmä zo strany tureckej vlády a čiastočne zo strany misie UNFICYP. Cyperská republika neprispela Hlavnému výboru žiadnym spôsobom. Počas siedmich rokov žili cyperskí Turci v chudobe v obmedzených kantónoch so strachom pred odplatou zo strany zástancov republiky, cyperských Grékov. ${ }^{52}$

Na druhej strane cyperskí Gréci ovládli po roku 1963 (po demonštratívnom odchode Turkov z vládnych funkcií) všetky štátne inštitúcie. Dominovali aj v hospodárskom živote. Grécko-cyperská spoločnosṫ zaznamenávala dynamický rast ekonomiky i životnej úrovne. Tureckú komunitu prevyšovali svojou vojenskou silou a mali na svojej strane podporu väčšiny ostatných krajín sveta, najmä vd’aka svojej aktívnej účasti v rôznych organizáciách medzinárodného spoločenstva, predovšetkým v OSN. ${ }^{53}$

50 Rezolúcia Rady Bezpečnosti OSN č. 186 zo dňa 4. 3. 1964. Internetový archív OSN, http://www.un.org/en/ ga/search/view_doc.asp?symbol=S/RES/186\%281964\%29, citováno 12. 3. 2018.

51 Rezolúcia Rady Bezpečnosti OSN č. 187 zo dřa 13.3.1964. Internetový archív OSN, http://www.un.org/en/ ga/search/view_doc.asp?symbol=S/RES/187\%281964\%29, citováno 12. 3. 2018.

52 Bora, E.: Cyprus in International Law, s. 38.

53 Majchút, I. - Hrnčiar, M.: Cyprus - dimenzie konfliktu, s. 89. 
Nepokoje na Cypre mali pre d’alšie dejiny ostrova jednoznačne negatívny vplyv. Nielenže sa nepodarilo spojit rozdelený národ, no ako vnútropolitické, tak aj zahraničnopolitické smerovanie vývoja cyperskej otázky nakoniec vyústilo v roku 1974 do tureckej invázie, ktorá de facto znamenala rozdelenie Cypru na grécku a tureckú čast. Ďalší vývoj z roku 1975, respektíve 1983, kedy cyperskí Turci vyhlásili deklaráciu nezávislosti Tureckej republiky severného Cypru, predstavoval prehĺbenie antagonistických vztahov. Cestu k vyriešeniu cyperského problému sa jeho aktérom nepodarilo nájst̉ dodnes.

Bolo by neobjektívne označit osobu či skupinu l’udí, ktorých by sme mohli určit za priamych pôvodcov postupného rozpadu zriadenia Cyperskej republiky v 60. rokoch 20. storočia. S najväčšou pravdepodobnostou spočívajú zárodky celého problému v období, kedy Cyperská republika ešte formálne neexistovala. Svoj podiel na rozpade Cyperskej republiky de facto mali nepochybne mocnosti vytvárajúce právny základ pre vytvorenie Cyperskej republiky, jej ústavy a „garančných“ dohôd počínajúc cez neústupnosṫ domácich politikov na Cypre v snahe nájst̉ kompromis a končiac 13. dodatkami k cyperskej ústave prezidenta Makaria. Je však nesporné, že zmluvy podpísané pred vznikom Cyperskej republiky a najmä, pre obe cyperské etniká rozporuplná ústava, mali na postupnom úpadku republiky vel'ký podiel. Cyperská ústava ${ }^{54}$ bola vo viacerých ohl'adoch jediná svojho druhu. Jej základná koncepcia politickej správy a ústavné rozdelenie nebolo najvhodnejšie. Prezentovaná rovnost’ v politickom postavení a nerovnomernej sile dvoch komunít v ich vel'kosti bolo nespravodlivé a svojím spôsobom neuskutočnitel'né. Nemožnost́ zmeny základných článkov cyperskej ústavy bola dovéšená zastavením akéhokolvek ústavného vývoja. Právo zahraničných mocností na intervenciu a zákaz niektorých ústavných zmien predstavovali značný prechmat na zvrchovanosti republiky.

Cyperská otázka zastáva v medzinárodnom kontexte nepochybne markantné postavenie. Špecifické postavenie cyperskej otázky v dejinách 20. storočia spočívalo najmä v angažovanosti sa jednotlivých krajín v udržiavaní mieru na ostrove, v pomoci vojnou najviac postihnutým lud’om a oblastiam, mediačnej činnosti, programom a plánom pre zmierenie a zblíženie oboch etník na ostrove či informovanosti o cyperskej problematike a takýmto príkladom z cyperských dejín odvrátit možné kolapsy v iných krajinách sveta. O situáciu na ostrove sa v druhej polovici 20. storočia okrem „pôvodcov cyperskej nezávislosti“ - Grécka, Turecka a Vel'kej Británie, začala zaujímat aj OSN a jej členské štáty či hlavní aktéri studenej vojny Spojené štáty americké a Sovietsky zväz.

Práve Spojené štáty americké javili o dianie na Cypre eminentný záujem a nadviazali priaznivé diplomatické styky s Cyperskou republikou. Mali na to niekolko dôvodov, spomeniem zrejme najvýraznejšie - silná pozícia komunistickej strany AKEL na Cypre a snaha zadržat šírenie vplyvu komunizmu na ostrove, možný konflikt medzi Gréckom a Tureckom a tým oslabenie juhovýchodného krídla NATO či vlastný vplyv a záujmy USA na ostrove v tomto strategickom regióne a pod. Vláda Spojených štátov amerických preto

54 Samotná ústava Cyperskej republiky je z pohl’adu historikov svojim spôsobom jedinečná. Z dnešného pohladu je niektorými autormi porovnávaná s ústavou a zriadením Bosny a Hercegoviny, i ked’ s istými podstatnými odlišnostami. Komparácia týchto dvoch špecifických dokumentov a štátnych zriadení je dnes výskumnou problematikou predovšetkým pre politológov. 
tlačila prakticky počas celej druhej polovice 20. storočia na svojich spojencov v NATO Vel'kú Britániu, Grécko a Turecko, aby cyperský problém vyriešili.

Ako spojené štáty, tak aj Sovietsky zväz patrili medzi krajiny, ktoré ako prvé uznali nezávislost’ Cyperskej republiky. Sovietsky zväz pozoroval situáciu na Cypre a možno konštatovat, že na ostrov mal nepriamy vplyv a v oficiálnych vyjadreniach zastával nezávislost a územnú integritu mladej republiky. Najsilnejším sformovaným politickým subjektov v Cyperskej republike na začiatku 60. rokov 20. storočia bola cyperská komunistická strana AKEL. Čiastočné napojenie a podpora strany AKEL pre Makaria v kombinácii s jeho neskrývaným orientovaním na Hnutie nezúčastnených bolo vnímané v Sovietskom zväze pozitívne.

Pri zamýšlaní sa nad všeobecnými dejinami Európy v 20. storočí možno konštatovat, že každá európska krajina má svoje vlastné „rozpady, rozkoly a konce“, Cyperská republika nevynímajúc. No všetky rozpady, rozkoly a konce však tvoria zároveň nové začiatky.

\section{To the breakdown of the Republic of Cyprus in 60 years of $20^{\text {th }}$ century}

The history of Cyprus question together with a process of creation of the Republic of Cyprus in 1960 represents significant episode in modern history of the third largest island in Mediterranean. The Republic of Cyprus was created after turbulent 50 s of $20^{\text {th }}$ century. This period in modern history of Cyprus is characterised through significant global diplomatic struggles of Greek-Cypriots and negotiations with government of Her Majesty. Greek-Cypriots begin their strife against British in 1955 in struggle to achieve enosis - union with Greece. On the other side, Turkish-Cypriots start with their claim to achieve taksim - partition of island between the two communities. This conflict ceased with a series of diplomatic negotiation which leads into the creation of the Republic of Cyprus. But disagreements between two official nationalities in this new state emerged soon. The main problems of young state were presented in constitution of the Republic of Cyprus. There we should find first disagreements dedicated to communal chambers and municipalities, structure of Cypriot army and proportion of nationalities in state offices. This so called Cypriot constitutional crises leads in late 1963 into ethnic conflict between Greek and Turkish Cypriots and became a seed to partition of the island. Purpose of this contribution aimed at summary of specification of successive breakdown of genuine structures of the Republic of Cyprus in 1960-1963, together with main determinants and problems which caused the breakdown, mainly through accessible sources known in our surrounding. 